\title{
The use of TPH analytical data to estimate human health risk: practical approaches
}

\author{
B. Sarmiento, T. Goyanes, I. Coleto \& N. De las Casas \\ URS Madrid, Spain
}

\begin{abstract}
This paper describes the three basic approaches that have been used to estimate potential human health risks posed by TPH contamination: the indicator approach, the surrogate approach and a mixed version.

Differences among methods are discussed in a case study: a former industrial area impacted with petroleum products, destined to be redeveloped for recreational use. Three exposure pathways have been considered: hydrocarbon vapor inhalation, ingestion and dermal contact. Firstly, only "indicator compounds" were evaluated. Next, the product was considered as gasoline in the Quantitative Risk Assessment. Afterwards, simple fractionation of hydrocarbon chains was introduced as the input parameter. Finally, the fractionation between the aromatic and aliphatic terms of each group of hydrocarbons was considered. Site-Specific Target Levels (SSTLs) for each pathway were calculated.

Results for different hypothesis have been evaluated from a technical and economic point of view. Cases in which input concentration for a compound was above soil saturation limit are also discussed.

Keywords: hydrocarbon, TPH, human health, indicator, whole product, TPH fraction, soil saturation, SSTL.

\section{Introduction}

Contamination of soils and groundwater by petroleum products can pose a risk to human health and environmental receptors. Petroleum products are complex mixtures containing primarily hydrocarbons. The toxicological evaluation of petroleum hydrocarbons is particularly difficult because these substances are present in the environment containing many hundreds of individual compounds, each with their own toxicological properties and environmental behavior. In
\end{abstract}


addition, once a spill is released into the environment, changes in composition may occur as a result of physical, chemical and biological weathering processes. One of the parameters assessed for determining petroleum contamination is referred to as total petroleum hydrocarbon (TPH). TPH is defined as "the measurable amount of petroleum-based hydrocarbon in an environmental media" (CONCAWE 2003).

There are three basic approaches used to estimate potential human health risks posed by TPH contamination: the "Indicator" Approach, used mostly for the evaluation of the carcinogenic risks from TPH; the "Surrogate" Approach, which assumes that a single compound can characterize TPH; and a "Compromised Version", in which an intermediate approach between the Indicator and Surrogate methods is applied.

\section{The indicator approach}

This approach assumes that the toxicity of a petroleum mixture is characterized by the toxicity of one or more of the most toxic compounds. For sites contaminated by gasoline and jet fuel, the most often selected compounds are benzene, toluene, ethylbenzene and xylenes (BTEX). Polycyclic Aromatic Hydrocarbons (PAHs) are considered of concern when evaluating kerosene and fuel oils. ASTM follows this approach, and generally accepts it only for carcinogenic risks, considering mainly benzene and benz(a)pyrene as indicator compounds.

\section{The surrogate approach}

The Surrogate Approach assumes that a single surrogate compound can characterize the TPH. This approach can overestimate the risks, as benzene, which is a highly volatile and soluble compound and is assessed as a carcinogenic type $\mathrm{A}$, is often considered as the surrogate compound for all aromatics. This approach has evolved to a fraction approach (see section 4).

A variant of the Surrogate Approach, the Whole Product Approach, is based on studies that consider the toxicity and mobility of the product as a whole. Most of these studies have been developed upon recent petroleum products, so risks posed by weathered substances can not been fully characterized.

\section{The compromised version}

At present, a compromise between the Indicator and the Surrogate Approaches is usually undertaken. Carcinogenic risk is estimated based on indicators (benzene, benzo(a)pyrene) and non-carcinogenic risk is calculated based on a number of $\mathrm{TPH}$ fractions. In this case, the surrogate would be an individual compound or a number of compounds within each TPH fraction that would be representative of the toxicity of the whole fraction. TPH can be divided into groups or fractions according to toxicity and transport properties. MADEP (1994) and TPHCWG (1999) have divided TPH mainly into aliphatic and aromatic compounds. The six carbon ranges identified by MADEP were based on differences in toxicity, while 
TPHCWG established 13 fractions based on the "equivalent carbon" index, which is related to the expected environmental behavior of individual petroleum compounds. Conservative toxicity data were developed for each fraction, prioritizing mixture data. To avoid double counting, indicator substances must be subtracted from the corresponding mass fraction. Both, MADEP and TPHCWG, assume additivity of non-carcinogenic toxicity across the fractions. Fraction approach accounts for the age and weathering of the spilled product and allows the evaluation of one or more petroleum products.

\section{Case study}

A former hydrocarbon distribution facility will be decommissioned and the terrain will be redeveloped for recreational use. The main product stored was unleaded gasoline. During an environmental investigation some quantities of product were found on the surface soil, therefore a human health risk assessment was performed. The three approaches described above were developed.

\subsection{Conceptual model}

The facility is located on a former industrial area in the process of being dismantled. It is about $5,000 \mathrm{~m}^{2}$. The Urban Plan contemplates the property as a future park.

Various hydrocarbon stains were found on the superficial soil at a depth of 20 $\mathrm{cm}$. The largest stain was of $10 \mathrm{~m}$ length. The contaminated terrain is a fill material, consisting of gravel in a sandy-silty matrix. This material overlies a 10 $\mathrm{m}$ layer of low-permeability, natural clays. No groundwater was found at the site.

Users of the park (adults and children) were identified as potential sensitive receptors of the contamination detected. Three exposures pathways were considered: outdoor inhalation of vapors, accidental ingestion of soil and dermal contact with soil.

\subsection{Procedures}

The Quantitative Risk Assessment includes the following steps: Exposure assessment, Toxicity assessment and Risk characterization.

The exposure assessment estimates the type and magnitude of exposures to the chemicals of potential concern that are present at or migrating from a site. In this case study, the ASTM E-1739-95 Outdoor Model was used to estimate outdoor vapor concentration. The ingestion and dermal contact exposures were calculated by means of the equations presented in US EPA RAGs (p 6-40, 6-41). Exposure factors, site and model data are summarized in tables 1 and 2 . The results of the exposure assessment are then combined with the chemical-specific toxicity information to characterize potential risks. Toxicity data applied in this assessment come from Integrated Risk Information System database (IRIS), the National Center for Environmental Assessment (NCEA) and TPHCWG. For carcinogens, the risk target level was established at 1.00E-05. Therefore any estimated risk over this value will indicate a potential threat due to the exposure 
to carcinogenic compounds. The non-carcinogenic effects are evaluated by comparing an exposure level over a specified time period with a reference dose derived for a similar exposure period. This ratio of exposure to toxicity is called a hazard quotient. The non-cancer hazard quotient target level is established as 1.00 .

Table 1: $\quad$ Exposure factors.

\begin{tabular}{|c|c|c|c|}
\hline \multicolumn{4}{|c|}{ Receptor input data } \\
\hline Characteristics & Units & Child Resident & Source \\
\hline \multicolumn{4}{|l|}{ Lifetime and body weight } \\
\hline Lifetime & years & 70 & ASTM 1995 \\
\hline Body weight & $\mathrm{Kg}$ & 15 & ASTM 1995 \\
\hline \multicolumn{4}{|l|}{ Inhalation of outdoor air } \\
\hline $\begin{array}{l}\text { Exposure frequency for Outdoor Air } \\
\text { events }\end{array}$ & events/yr & 350 & ASTM 1995 \\
\hline Exposure duration for outdoor air & years & 6 & ASTM 1995 \\
\hline Lung retention factor & - & 1 & ASTM 1995 \\
\hline Inhalation rate outdoors & $\mathrm{m}^{3} / \mathrm{hr}$ & 1.2 & $\begin{array}{c}\text { ECETOC } \\
2001 \\
\end{array}$ \\
\hline Time outdoors & $\mathrm{hr} /$ day & 24 & Hypothesis \\
\hline \multicolumn{4}{|c|}{ Ingestion of soil/ dermal contact with soil during leisure activities } \\
\hline Exposure frequency for soils & events/yr & 350 & ASTM 1995 \\
\hline Exposure duration for soils & years & 6 & ASTM 1995 \\
\hline Ingestion rate for soil & $\mathrm{mg} /$ day & 200 & $\begin{array}{c}\text { ECETOC } \\
2001 \\
\end{array}$ \\
\hline Total skin surface area & $\mathrm{cm}^{2}$ & 7640 & $\begin{array}{l}\text { ECETOC } \\
2001 \\
\end{array}$ \\
\hline Fraction skin exposed to soil & - & 0.52 & $\begin{array}{l}\text { ECETOC } \\
2001\end{array}$ \\
\hline Soil/skin adherence factor & $\mathrm{mg} / \mathrm{cm}^{2}$ & 0.22 & $\begin{array}{l}\text { ECETOC } \\
2001\end{array}$ \\
\hline
\end{tabular}

Note: Only the child receptor was considered for this case study since it is normally the most sensitive receptor. For this purpose, maximum exposure factors have been taken into account.

Table 2: $\quad$ Site and box model parameters.

\begin{tabular}{|l|c|c|c|}
\hline \multicolumn{4}{|c|}{ Unsaturated zone properties and source data for vapor model (gravel) } \\
\hline Characteristics & Units & Value & Source \\
\hline Total porosity & $\mathrm{cm}^{3} / \mathrm{cm}^{3}$ & 0.3 & Site specific \\
\hline Water content & $\mathrm{cm}^{3} / \mathrm{cm}^{3}$ & 0.1 & Site specific \\
\hline Distance from soil source to ground surface & $\mathrm{m}$ & 0.2 & Site specific \\
\hline Fraction organic carbon in source & goc/g soil & 0.002 & Site specific \\
\hline Soil bulk density & $\mathrm{g} / \mathrm{cm}^{3}$ & 1.7 & Site specific \\
\hline \multicolumn{4}{|c|}{ Box model parameters } \\
\hline Height of box & $\mathrm{m}$ & 2 & ASTM 1995 \\
\hline Length of box (in direction of wind flow) & $\mathrm{m}$ & 10 & ASTM 1995 \\
\hline Wind speed & $\mathrm{m} / \mathrm{s}$ & 2.25 & ASTM 1995 \\
\hline
\end{tabular}




\subsection{Developing approaches}

\subsubsection{Approach 1: indicator approach}

BTEX and MTBE were considered as indicator compounds of the hydrocarbons present as, according to site historical data, the main product stored was gasoline. Samples were analyzed according to ISO 11423-1/CMA 3/E. Maximum concentration detected is included in table 3:

Table 3: Input concentration for indicator compounds.

\begin{tabular}{|c|c|}
\hline Compound & Input Concentration $(\mathrm{mg} / \mathrm{kg})$ \\
\hline Benzene & 26 \\
\hline Toluene & 28 \\
\hline Ethylbenzene & 22 \\
\hline Xylenes & 67 \\
\hline MTBE & 111 \\
\hline TOTAL & 254 \\
\hline
\end{tabular}

Risks levels are summarized in section 5.4. According to this approach, SoilSpecific Target Levels (SSTLs) were calculated for individual compounds. Laboratory costs for BTEX compounds are on the range of $96 € /$ sample.

Table 4: $\quad$ Estimated composition of the mixture.

\begin{tabular}{|c|c|c|}
\hline Compound & $\%$ & $\begin{array}{c}\text { Estimated stain } \\
\text { concentration }(\mathrm{mg} / \mathrm{kg})\end{array}$ \\
\hline Aliphatics & Aliphatics & Aliphatics \\
\hline C5-C6 & 46 & 10,956 \\
\hline C6-C8 & 12 & 2858 \\
\hline C8-C10 & 7 & 1667 \\
\hline C10-C12 & 0.27 & 64 \\
\hline C12-C16 & - & - \\
\hline C16-C35 & - & 15,546 \\
\hline TOTAL & $65 \%$ & Aromatics \\
\hline Aromatics & Aromatics & 452 \\
\hline C6-C7 & 2 & 4477 \\
\hline C7-C8 & 19 & 1736 \\
\hline C8-C10 & 7 & 1669 \\
\hline C10-C12 & 7 & - \\
\hline C12-C16 & - & - \\
\hline C16-C21 & - & 8336.3 \\
\hline C21-C35 & - & \\
\hline TOTAL & $35 \%$ & \\
\hline & & - \\
\hline
\end{tabular}

\subsubsection{Approach 2: surrogate approach}

The "Whole Product Approach" was developed in this example. The main product presented at the site was Gasoline. Samples were analyzed for TPH in 
accordance with standard ISO-CMA 3/R. The maximum concentration obtained was $23,818 \mathrm{mg} / \mathrm{kg}$. The first column in Table 4 presents the average composition of a gasoline according to TPHCWG. In the second column, the estimated composition of the mixture (considering a total concentration of $23,818 \mathrm{mg} / \mathrm{kg}$ ) is shown.

Risk levels are presented on section 5.4. SSTLs were calculated for the mixture, first considering only non-carcinogenic compounds and then considering the whole mixture. SSTLs for TPH were calculated by weighting individual fractions according to their composition in the total petroleum mixture and assuming their toxic effects are additive.

The normal laboratory price would be $56 € /$ sample for obtaining the sum amount of TPH.

\subsubsection{Approach 3: compromised version}

Carcinogenic risk was estimated based on benzene as the indicator compound. Non-carcinogenic risk from the TPH was calculated based on fractions. Two cases were analyzed: Case A, where a simple division of TPH into chains was performed in the laboratory, without distinguishing between aliphatic and aromatic fractions (CMA 3/R method); and Case $\mathrm{B}$, where this aliphaticaromatic division was made (US EPA Method 8270). In case A, it was not possible to determine what percentage of TPH fractions belonged to aliphatic and which to aromatic compounds, therefore fractions have been duplicated in order to avoid underestimating the risk.

Analytical costs for Case A are $75 € /$ sample and Case B are $125 € /$ sample, plus the $96 € /$ sample in both cases for benzene.

Table 5: $\quad$ Cases contemplated on the third approach.

\begin{tabular}{|c|c|c|c|}
\hline \multicolumn{2}{|c|}{ Case A } & \multicolumn{2}{c|}{ Case B } \\
\hline Aliphatics & $\begin{array}{c}\text { Concentration } \\
(\mathrm{mg} / \mathrm{kg})\end{array}$ & Aliphatics & $\begin{array}{c}\text { Concentration } \\
(\mathrm{mg} / \mathrm{kg})\end{array}$ \\
\hline C5-C6 & 115 & C5-C6 & 90 \\
\hline C6-C8 & 1388 & C6-C8 & 1360 \\
\hline C8-C10 & 600 & C8-C10 & 204 \\
\hline C10-C12 & 362 & C10-C12 & 145 \\
\hline C12-C16 & 7277 & C12-C16 & 6782 \\
\hline C16-C35 & 14076 & C16-C35 & 13,966 \\
\hline TOTAL & $23,818(100 \%)$ & TOTAL & $22,547(94.66 \%)$ \\
\hline Aromatics & $\begin{array}{c}\text { Concentration } \\
(\mathrm{mg} / \mathrm{kg})\end{array}$ & Aromatics & $\begin{array}{c}\text { Concentration } \\
(\mathrm{mg} / \mathrm{kg})\end{array}$ \\
\hline C6-C7 & 115 & C6-C7 & 25 \\
\hline C7-C8 & 1388 & C7-C8 & 28 \\
\hline C8-C10 & 600 & C8-C10 & 396 \\
\hline C10-C12 & 362 & C10-C12 & 217 \\
\hline C12-C16 & 7277 & C12-C16 & 495 \\
\hline C16-C21 & 6887 & C16-C21 & 105 \\
\hline C21-C35 & 7189 & C21-C35 & 5 \\
\hline TOTAL & $23,818(100 \%)$ & TOTAL & $1,271(5.34 \%)$ \\
\hline
\end{tabular}




\subsection{Results}

Results for the three approaches considered are presented in table 6. Risk summary is considered for each pathway. The non-carcinogenic reference level is $1.00 \mathrm{E}+00$ and $1.00 \mathrm{E}-05$ for carcinogenic reference level (see section 5.2).

Table 6: $\quad$ Estimation of the non-carcinogenic risk

\begin{tabular}{|l|c|c|c|}
\hline \multicolumn{1}{|c|}{ Approaches } & Ingestion & Dermal contact & $\begin{array}{c}\text { Outdoor vapor } \\
\text { inhalation }\end{array}$ \\
\hline Indicator* & $9.20 \mathrm{E}-02$ & $3.70 \mathrm{E}-02$ & $\mathbf{4 . 8 0 E}+\mathbf{0 1}$ \\
\hline Whole Product & $\mathbf{1 . 7 0 E}+\mathbf{0 0}$ & $6.60 \mathrm{E}-01$ & $\mathbf{3 . 2 0 E}+\mathbf{0 0}$ \\
\hline $\begin{array}{l}\text { Case A: Aliphatic } \\
\text { Fraction }\end{array}$ & $\mathbf{1 . 1 0 E}+\mathbf{0 0}$ & $4.60 \mathrm{E}-01$ & $1.70 \mathrm{E}-01$ \\
\hline $\begin{array}{l}\text { Case A: Aromatic } \\
\text { Fraction }\end{array}$ & $\mathbf{8 . 7 0 E}+\mathbf{0 0}$ & $\mathbf{3 . 5 0 E}+\mathbf{0 0}$ & $\mathbf{2 . 0 0 E}+\mathbf{0 0}$ \\
\hline $\begin{array}{l}\text { Case B: real } \\
\text { fractioning }\end{array}$ & $\mathbf{1 . 4 0 E}+\mathbf{0 0}$ & $5.60 \mathrm{E}-01$ & $4.70 \mathrm{E}-01$ \\
\hline
\end{tabular}

*In the indicator approach risks should not be summed as it is considered inappropriate to sum hazard indices unless the toxicological endpoints and mechanisms of action are the same for individual compounds. "Lack of sufficient toxicological information is an impediment to this procedure" (ASTM E-1739-95, p. 198). The sum was considered in this case study just to compare the results obtained with the other approaches considered.

Most of the risk results from the ingestion and vapor inhalation pathways.

Both Case B and Case A Aliphatics, are quite similar, as the real mixture is made of a $95 \%$ aliphatic compounds. On the other hand, risk values for Case A Aromatics are about four to six times higher than those obtained for the other two cases. This is due to the fact that aromatic compounds are, in general, more toxic and soluble than aliphatics. Moreover, a concentration of $23,818 \mathrm{mg} / \mathrm{kg}$ is being evaluated in the single case instead of the real aromatic concentration of $1.271 \mathrm{mg} / \mathrm{kg}$, used in Case B (see table 5).

Results obtained for the Whole Product Approach are consequent with those obtained for the Compromised Version. For outdoor vapor inhalation, risks are higher in the Whole Product than for Case B due to a higher concentration of aromatics (see table 4). In the Indicator Approach, risks are 100\% superior in comparison to Case $\mathrm{B}$, because benzene is considered as an individual compound, whose inhalation reference dose is two orders of magnitude higher than that of its equivalent aromatic fraction C6-C7, considered in Case B. Moreover, according to TPHCWG the solubility and volatility of a compound decrease when a compound is present in the mixture when compared to its behavior when it is found pure. On the contrary, the risk values for the direct pathways are being underestimated in the Indicator Approach, as only a few compounds (BTEX and MTBE) were considered, and these compounds only sum $254 \mathrm{mg} / \mathrm{kg}$ instead of the $23,818 \mathrm{mg} / \mathrm{kg}$ of the total mixture (see Table 3 ). 
Table 7: $\quad$ Estimation of carcinogenic risks.

\begin{tabular}{|l|c|c|c|}
\hline \multicolumn{1}{|c|}{ Approaches } & Ingestion & Dermal contact & $\begin{array}{c}\text { Outdoor vapor } \\
\text { inhalation }\end{array}$ \\
\hline Indicator* & $2.0 \mathrm{E}-06$ & $7.8 \mathrm{E}-07$ & $\mathbf{7 . 2 E - 0 4}$ \\
\hline Whole Product & $\mathbf{2 . 7 0 E - 0 5}$ & $\mathbf{1 . 1 0 E - 0 5}$ & $\mathbf{1 . 3 0 E - 0 4}$ \\
\hline $\begin{array}{l}\text { Case A: Aliphatic } \\
\text { Fraction }\end{array}$ & $1.60 \mathrm{E}-06$ & $6.20 \mathrm{E}-07$ & $\mathbf{2 . 8 0 E - 0 5}$ \\
\hline $\begin{array}{l}\text { Case A: Aromatic } \\
\text { Fraction }\end{array}$ & $1.60 \mathrm{E}-06$ & $6.20 \mathrm{E}-07$ & $\mathbf{2 . 2 0 E - 0 5}$ \\
\hline $\begin{array}{l}\text { Case B: real } \\
\text { fractioning }\end{array}$ & $1.60 \mathrm{E}-06$ & $6.20 \mathrm{E}-07$ & $\mathbf{2 . 8 0 E - 0 5}$ \\
\hline
\end{tabular}

No risk values exceeding the reference value were obtained for the direct pathways, except in the Whole Product Approach, in which estimated benzene concentration is about $452 \mathrm{mg} / \mathrm{kg}$ (corresponding to aromatics C6-C7, with a $2 \%$ of the total mixture) instead of the $26 \mathrm{mg} / \mathrm{kg}$ considered in the rest of approaches. The same level of risk was obtained for the direct pathways, as the TPH was not considered as a mixture. Risk levels for the vapor inhalation pathway where identified for all of the studied approaches. Risks values were higher when considering benzene as an individual compound instead of considering it as a part of a mixture.

The following table presents the clean-up levels estimated from the risks considered in each approach:

Table 8: $\quad$ SSTLs for TPH / TPH with Benzene / Benzene.

\begin{tabular}{|l|l|l|}
\hline Approaches & $\begin{array}{c}\text { Ingestion+ Dermal contact } \\
(\mathrm{mg} / \mathrm{kg})\end{array}$ & \multicolumn{1}{|c|}{$\begin{array}{c}\text { Outdoor vapor inhalation } \\
(\mathrm{mg} / \mathrm{kg})\end{array}$} \\
\hline Indicator & Benzene: 120 & $\begin{array}{l}\text { Benzene: } 0.37 \\
\text { Ethylbenzene: } 82 \\
\text { Ethylbenzene: } 5,600\end{array}$ \\
& Toluene: 11,000 & Toluene: 18 \\
& Xylenes: 11,000 & Xylenes: 67 \\
& MTBE: 2,000 & $83 / 35 / 0.41$ \\
\hline Whole Product & $10,000 / 5,300 / 120$ & $\mathrm{RES} / 380 / 0.42$ \\
\hline Case A: Aliphatic Fractions & $15,000 / 14,000 / 120$ & $300 / 210 / 0.41$ \\
\hline Case A: Aromatic Fractions & $2,000 / 1,900 / 120$ & $\mathrm{RES} / 460 / 0.48$ \\
\hline Case B: real fractioning & $12,000 / 11,000 / 12$ &
\end{tabular}

The most restrictive SSTL was obtained for benzene vapor inhalation in the Indicator Approach $(0.37 \mathrm{mg} / \mathrm{kg})$. On the other hand, when benzene is considered as a part of a mixture, the SSTLs increase depending on the composition of the mixture.

The application of the Whole Product Approach could result in higher costs of remediation and very difficult to obtain clean up goals $(83 \mathrm{mg} / \mathrm{kg}$ for TPH).

Case A of the Compromised Approach cannot be considered as an appropriate solution as risks are overestimated compared with Case B (an SSTL of $12,000 \mathrm{mg} / \mathrm{kg}$ could be applied instead of $210 \mathrm{mg} / \mathrm{kg}$ if benzene were not in 
the soil). Results become similar when considering benzene, although they are much more restrictive for Case A.

Note that for the third approach, in Case A Aliphatic and Case B the SSTLs exceed the residual concentration for any of the chemicals evaluated as part of the particular mixture considered (RES). This means that there will be no risk at any given concentration, except when considering benzene.

\subsection{Considerations to soil saturation}

Soil saturation concentration is the theoretical soil concentration at which the solubility limits of the soil pore water, the vapor phase limits of the soil pore air and the adsorptive limits of the soil particles have been reached.

Considering only vapor inhalation outdoor in case B of the fraction approach, it would be possible to leave $23,818 \mathrm{mg} / \mathrm{kg}$ of TPH in soil, as there will be no risk since, theoretically, volatile emissions will not increase above this level. But it is difficult to accept that such a concentration could be left in the soil. MADEP recommends a "ceiling value" of $500-1,000 \mathrm{mg} / \mathrm{kg}$ in sites contaminated by gasoline considering odors and esthetic criteria. TPHCWG establishes values from 5,000 to $10,000 \mathrm{mg} / \mathrm{kg}$ for sites affected by crude oils and when benzene is not present.

\subsection{Conclusions}

The implementation of the Compromised Approach can be considered as the most appropriate for the evaluation of risks posed by petroleum hydrocarbons. Decomposition of the mixture between aliphatic and aromatic chains (Case B) should be undertaken as the lack of knowledge in Case A can result in an expensive overestimation of risks. Due to higher laboratory cost for Case B it may not be possible to perform this type of analysis on every sample in restricted budget investigations, but it should be recommended at least for the most representative samples of the contamination detected.

The Indicator Approach, as expected, was appropriate when evaluating carcinogenic risks, although a slightly overestimated SSTL for benzene was obtained. Nevertheless, the risks for the non-carcinogenic compounds were underestimated.

The Whole Product Approach overestimated both carcinogenic and noncarcinogenic risks in this case study, as the composition of the product detected did not correspond to the gasoline considered.

\section{References}

[1] ASTM Standard E1739-95 Guide for Risk-Based Corrective Action Applied al Petroleum Release sites, American Society for Testing Materials, Philadelphia, 1995.

[2] ASTM Standard E2081-00 Standard Guide for Risk Based Corrective Action, American Society for Testing Materials, Philadelphia, 2000. 
[3] CONCAWE Report no 3/03 Guideline for Risk-Based Assessment of Contaminated Sites (revised), European Oil Industry, Brussels, 2003.

[4] MaDEP Interim Final Petroleum Report: Development of Health Based Alternative to the Total Petroleum Hydrocarbon (TPH) Parameter, Massachusetts Department of Environmental Protection, Boston, 1994.

[5] MaDEP Characterizing Risks Posed by Petroleum Contaminated Sites: Implementation of the MADEP VPH/EPH Approach. Draft for Public Comment, Massachusetts Department of Environmental Protection, Boston, 1997.

[6] TPHCWG, Total Petroleum Hydrocarbon Criteria Working Group Series (Volumes 1,2,3,4,5), Amherst Scientific Publishers, Amherst, Massachusetts, 1997-1999.

[7] US EPA EPA540/1-89/002 Risk Assessment Guidance for Superfund Volume I, Human Health Evaluation Manual (Part A) Interim Final, Office of Emergency and Remedial Response, U.S Environmental Protection Agency, Washington 1989. 